\title{
Use of Degenerate Primers for Partial Sequencing and RT-PCR-Based Assays of Grapevine Leafroll-Associated Viruses 4 and 5
}

\author{
Geoffrey Routh, Yun-Ping Zhang, Pasquale Saldarelli, and Adib Rowhani
}

First, second, and fourth authors: Department of Plant Pathology, University of California, Davis 95616; and third author: Centro di Studio sui Virus e le Virosi, Delle Colture Mediterranee-CNR, Via Amendola 165\A, 70126-Bari, Italy.

Current address of G. Routh: Thermalytics Inc., West Sacramento, CA 95691.

Accepted for publication 28 July 1998.

\begin{abstract}
Routh, G., Zhang, Y.-P., Saldarelli, P., and Rowhani, A. 1998. Use of degenerate primers for partial sequencing and RT-PCR-based assays of grapevine leafroll-associated viruses 4 and 5. Phytopathology 88:1238-1243.

Double-stranded RNA (dsRNA) was purified from grapevines infected with grapevine leafroll-associated viruses 4 (GLRaV-4) and 5 (GLRaV-5), two putative closteroviruses. Reverse-transcriptase polymerase chain reaction (RT-PCR) was performed on this dsRNA using degenerate oligonucleotides designed to amplify an approximately 550- to 650-nucleotide fragment from the heat shock protein 70 homolog (HSP70) of the known closteroviruses. RT-PCR products of the appropriate molecular weight were gel-isolated and cloned into the plasmid vector pGEM-T. Clones of RTPCR products generated by using these primers on dsRNA isolated from

a plant infected with GLRaV-4 were sequenced. This sequence was used to develop an immunocapture RT-PCR (IC-RT-PCR) detection protocol capable of detecting GLRaV-4. Similar clones were made from dsRNA isolated from a plant infected with GLRaV-5. These clones were also sequenced. The two sequences were compared, and RT-PCR primers were developed that were able to amplify cDNA from both. These experiments demonstrate that degenerate primers that amplify closterovirus HSP70 sequences can be used to successfully generate sequences useful for ICRT-PCR detection of these viruses. These data also suggest that it is feasible to use HSP70 sequences to design PCR primers capable of more general PCR detection of multiple GLRaV serotypes. Lastly, the presence of closterovirus-like HSP70 sequences in these putative closteroviruses implies that they are indeed members of this taxonomic group.
\end{abstract}

Grapevine leafroll disease causes poor color development and nonuniform maturation of fruit in Vitis vinifera (10). Additional symptoms can include downward rolling of basal leaves followed by rolling of the leaves near the shoot tips, color change and necrosis in the interveinal portions of the leaves, and phloem disruption $(14,33)$. This condition has been associated with yield losses of as much as 20 to $40 \%(9,34)$. The symptoms of grapevine leafroll disease can resemble those caused by mechanical damage to the trunk, other diseases of the phloem tissue, and arthropod damage, thereby complicating visual diagnosis (33).

Currently, there are at least seven distinct putative closteroviruses associated with this disease $(5,6,15,16,23,30,36)$, collectively referred to as grapevine leafroll-associated viruses (GLRaVs). Partial purification of these putative closteroviruses has allowed development of serological methods such as the enzyme-linked immunosorbent assay (ELISA) for their detection $(8,16,24,27,36)$. Serological detection of GLRaV, however, requires the availability of multiple antibody preparations capable of detecting all of the known types of this virus $(8,27)$. Since these putative closteroviruses can be distributed unevenly throughout the plant and viral titers vary considerably according to seasonal influences (12), more sensitive assays such as reverse-transcriptase polymerase chain reaction (RT-PCR) and immunocapture RT-PCR (IC-RT-PCR) would be useful. PCR primers capable of detecting more than one type would also reduce considerably the difficulty of GLRaV detection in grapevines.

Very little is known about the molecular genetics of the putative grapevine closteroviruses. Molecular characterization of these viruses has been impaired by difficulties associated with purifying

Corresponding author: A. Rowhani; E-mail address: akrowhani@ucdavis.edu

Publication no. P-1998-0922-02R

(C) 1998 The American Phytopathological Society viruses (16) and nucleic acids from grapevines (25); however, limited success has been achieved in cloning cDNA fragments from double-stranded RNA (dsRNA) extracted from grapevines infected with GLRaV-1, GLRaV-2, and GLRaV-3 (1,12,13,20,28,35). Degenerate RT-PCR primers exist that can be used to amplify a portion of a gene that encodes a heat shock protein 70 homolog (HSP70) present in all of the known closteroviruses (31). Here, we report on the use of these primers to quickly acquire cloned HSP70 fragments from dsRNA prepared from grapevines infected with GLRaV-4 and GLRaV-5. Additionally, we report the use of sequence information generated from these cloned PCR products to develop an IC-RT-PCR assay for detection of GLRaV-4 that does not cross-react with GLRaV-1, GLRaV-2, GLRaV-3, and GLRaV-5. We also report the development of a RT-PCR assay capable of detecting both GLRaV-4 and GLRaV-5 with a single primer set.

\section{MATERIALS AND METHODS}

dsRNA preparation. Initially, dsRNA was purified by phenol extraction of plant sap followed by two rounds of Whatman CF-11 cellulose chromatography (Whatman International, Ltd., Maidstone, England), sodium chloride precipitation of impurities, and digestion with DNase and RNase according to the method of Saldarelli et al. (28). Subsequent preparations were performed by the single CF-11 column procedure of Valverde et al. (32). GLRaV-4 dsRNA isolation was carried out on a V. vinifera cv. Cabernet Sauvignon vine infected with GLRaV isolate 106 (11). This plant consistently tested positive by ELISA for GLRaV-4 and negative for GLRaV-1, GLRaV-2, GLRaV-3, and GLRaV-5. The antibodies used in this study were described previously (27) or procured from Sanofi Phytodiagnostics (Marnes-La-Coquette, France) in the case of GLRaV-5. GLRaV-5 dsRNA was purified from a $V$. vinifera $\mathrm{cv}$. Emperor vine that is likewise only seropositive for this GLRaV serotype when tested with these antisera. Multiple tests were performed on leaves 
and cambium samples taken from locations covering the entire canopy of these plants. Six percent polyacrylamide gel electrophoresis (PAGE) was used to analyze dsRNA products. Tris-acetateEDTA (TAE) (29) was used as the running buffer, and the acrylamide to bisacrylamide ratio was $38: 1$.

Degenerate primer RT-PCR. RT-PCR was performed using the degenerate primers HSP-P-1 (GGNTTAGANTTCGGNACNAC) and HSP-P-2 (TCAAANGTNCCNCCNCCNAA) described by Tian et al. (31). These primers are designed to amplify an approximately 550- to 650-bp portion of the open reading frame encoding a HSP70 found in all of the known closteroviruses. For degenerate primer RT-PCR, GLRaV dsRNA was denatured with methylmercuric hydroxide and subjected to RT-PCR essentially as described by Tian et al. (31), except that the $\mathrm{MgCl}_{2}$ concentration was $4 \mathrm{mM}$ rather than $3 \mathrm{mM}$ and the amount of PAGE-purified primer (Gibco BRL, Grand Island, NY) was increased to $1 \mu \mathrm{g}$ (each primer) per reaction.

Cloning and sequencing PCR products. Products of the degenerate primer PCR reactions were subjected to gel electrophoresis (1\% agarose with TAE as the running buffer) according to Sambrook et al. (29), and DNA fragments of 550 to $650 \mathrm{bp}$ in length were recovered from the gel using the Gene Clean procedure (Bio 101 Inc., Vista, CA). These PCR products were then cloned into pGEM-T (Promega Corp., Madison, WI) and transformed into Escherichia coli DH5 $\alpha$ (max efficiency; Gibco BRL). Dot spot analyses were carried out to verify the specificity of one of the GLRaV-4 clones. This was done by denaturing dsRNA isolated from petioles of healthy and GLRaV-4-infected $V$. vinifera and binding it to positively charged nylon membranes (Boehringer Mannheim Biochemicals, Indianapolis, IN) according to Sambrook et. al. (29). A digoxigenin (DIG)-labeled RNA probe was transcribed from the clone, and hybridization experiments were performed according to protocols provided with the DIG/Genius nonradioactive labeling and detection kits (Boehringer Mannheim Biochemicals) using Lumigen purified protein derivative (Boehringer Mannheim Biochemicals) as the chemiluminescent substrate. Selected clones of GLRaV-4 and GLRaV-5 were subjected to DNA sequencing by an automated sequencing facility (ABI Prism 377 DNA sequencer; Perkin-Elmer, Foster City, CA) at the University of California, Davis. Both strands of multiple clones of each PCR product were sequenced in this manner.

Nucleotide sequence analysis. Deduced amino acid sequences from putative HSP70 clones were compared using the BLAST programs $(3,4)$ with protein sequences in the nonredundant sequence databases at the National Center for Biotechnology Information (National Institute of Health). Further comparisons between selected sequences were performed using the PileUp and Gap programs from the University of Wisconsin Genetics Computer Group (GCG) (7).

Preparation of plant sap extracts for IC-RT-PCR virus detection. Plant sap extracts for IC-RT-PCR virus detection were prepared from cortex and petiole tissue of healthy or infected grape vines $(V$. vinifera). Plant tissue was extracted in dilution buffer $(1: 10$, wt/vol; dilution buffer $=500 \mathrm{mM}$ Tris-Cl, $\mathrm{pH} 7.4$; $2 \%$ polyvinylpyrrolidone-40; $1 \%$ polyethylene glycol $8000 ; 140 \mathrm{mM}$ $\mathrm{NaCl}$; and $0.05 \%$ Tween-20 [26]) in mesh sample extraction bags (Agdia, Inc., Elkhart, IN) using a Homex 6 homogenizer (Bioreba AG, South Bend, IN).

IC-RT-PCR detection of GLRaV-4. Nucleotide sequences obtained during the course of this project were used to design a set of PCR primers intended to amplify a 441-bp cDNA fragment from the GLRaV-4 HSP70 gene. Primer HSP4A (CTCAAACCAGCGGCTGTTG) is complementary to the virion-sense RNA sequence and is used for reverse transcription as well as PCR. Primer HSP4B (GTGATACCATATACATACCGACC) matches the virionsense RNA sequence and is used in the PCR reaction. Immunocapture of GLRaV-4 virions was performed in microcentrifuge tubes as described by Rowhani et al. (26). Virions were then liberated from these tubes by incubating them for $2 \mathrm{~min}$ at $50^{\circ} \mathrm{C}$ with $50 \mu \mathrm{l}$ of $0.1 \%$ sodium dodecyl sulfate (SDS) and vortexing. For IC-RTPCR, $0.5 \mu \mathrm{l}$ of the immunocaptured virions in $0.1 \%$ SDS were added to $10 \mu \mathrm{l}$ of $10 \mathrm{mM}$ methylmercuric hydroxide and allowed to denature at room temperature for $10 \mathrm{~min}$ followed by reverse transcription for $45 \mathrm{~min}$ at $37^{\circ} \mathrm{C}$ in $20 \mu \mathrm{l}$ of reverse-transcription solution $(10.5 \mu \mathrm{l}$ of denatured RNA, $0.5 \mu \mathrm{l}$ of $1 \mu \mathrm{g} / \mu \mathrm{l}$ primer HSP4A,
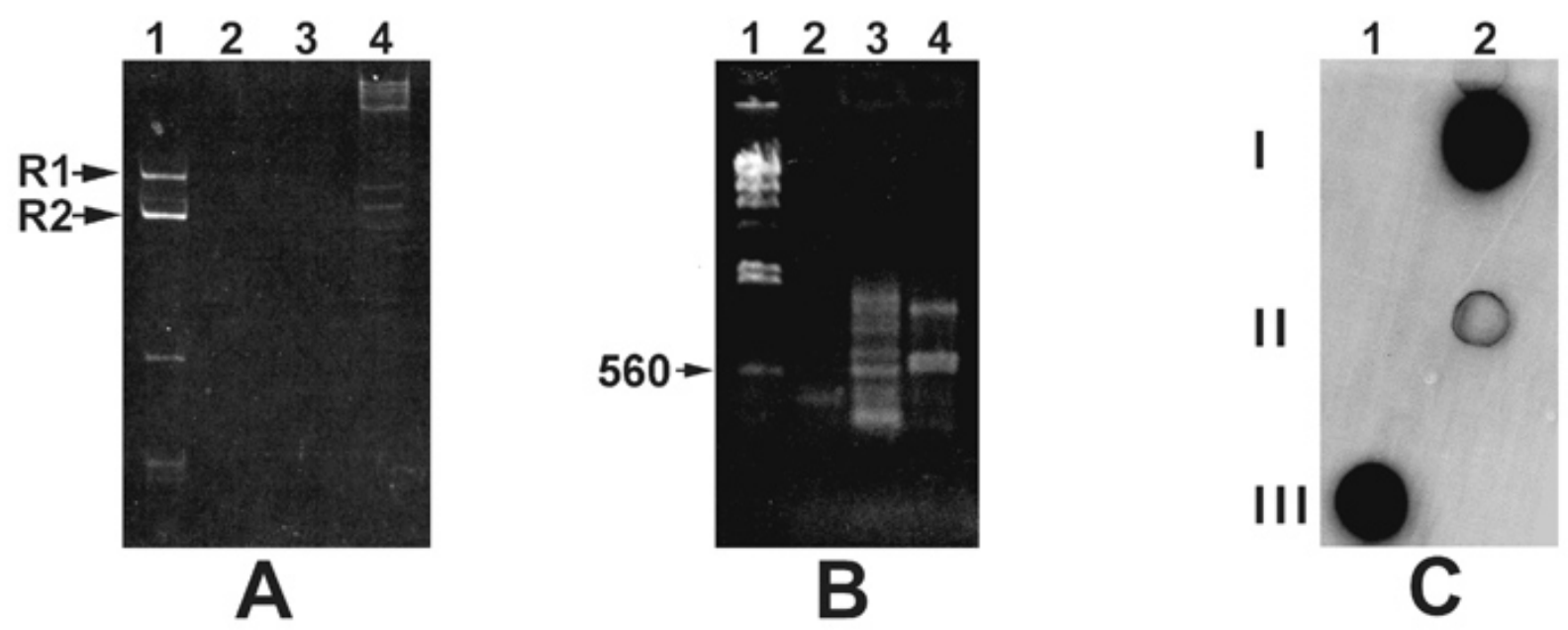

Fig. 1. Template preparation and cloning of a heat shock protein 70 homolog (HSP70) fragment of grapevine leafroll-associated virus 4 (GLRaV-4) doublestranded RNA (dsRNA). A, Acrylamide gel electrophoresis of cucumber mosaic virus (CMV) dsRNA isolated from $0.1 \mathrm{~g}$ of infected Nicotiana tabacum (lane 1), dsRNA isolated from $30 \mathrm{~g}$ of healthy Vitis vinifera (lane 2), loading buffer only (lane 3), and dsRNA isolated from $30 \mathrm{~g}$ of $\mathrm{V}$. vinifera infected with GLRaV-4 (lane 4). CMV RNAs 1 and 2 are labeled at the left of the gel (R1 and R2). B, Agarose gel electrophoresis (1.5\%) of $1 \mu \mathrm{g}$ of HindIII-cut bacteriophage lambda DNA (lane 1), the products of reverse-transcriptase polymerase chain reaction (RT-PCR) on dsRNA prepared from $20 \mathrm{~g}$ of uninfected V. vinifera (lane 2), dsRNA isolated from $20 \mathrm{~g}$ of $V$. vinifera infected with GLRaV-4 (lane 3), and dsRNA isolated from $0.5 \mathrm{~g}$ of Tetragonia expansa infected with beet yellows virus (lane 4). The degenerate primers used (31) were designed to amplify a 550- to 650-nucleotide (nt) fragment of the HSP70 gene from the known closteroviruses. The 560-nt bacteriophage lambda HindIII fragment (560) is indicated to the left of the gel. C, Dot spot analysis of loading buffer only (column 1, row I), 50 ng of cloned plasmid containing a GLRaV-4 RT-PCR product approximately 550 to $600 \mathrm{nt}$ in length (column 2, row I), dsRNA from $10 \mathrm{~g}$ of $V$. vinifera serologically negative for GLRaV-4 (column 1, row II), dsRNA from $10 \mathrm{~g}$ of $V$. vinifera infected with GLRaV-4 (column 2, row II), 10 ng of digoxigeninlabeled RNA probe transcribed from the cloned GLRaV-4 RT-PCR product and bound directly to the membrane (column 1, row III), and buffer only (column 2, row III). The membrane was hybridized with a digoxigenin-labeled probe transcribed from the cloned GLRaV-4 PCR product. 

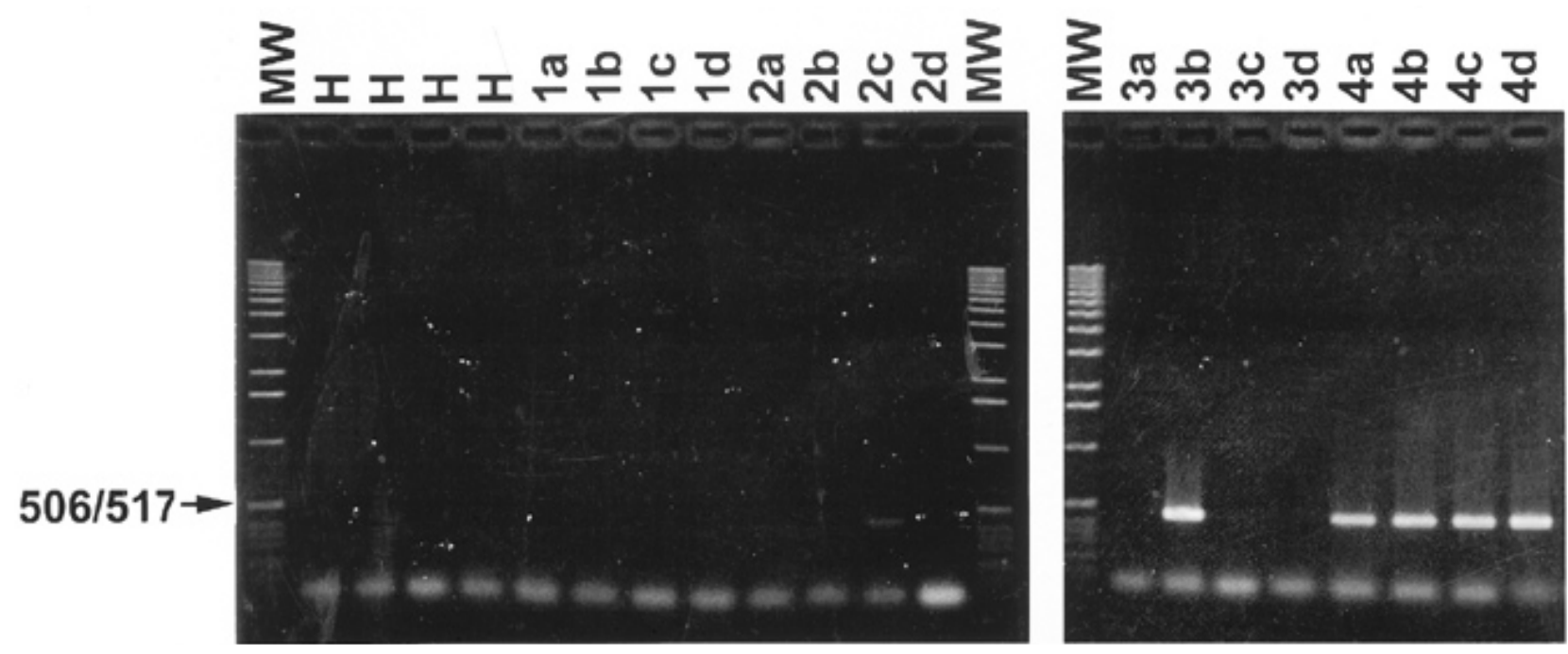

Fig. 2. Detection of grapevine leafroll-associated virus 4 (GLRaV-4) in Vitis vinifera by immunocapture reverse-transcriptase polymerase chain reaction (IC-RT-PCR). IC-RT-PCR was performed on four uninfected grapevines (marked "H") and on four vines enzyme-linked immunosorbent assay (ELISA) positive for GLRaV-1 (1a to d), GLRaV-2 (2a to d), GLRaV-3 (3a to d), and GLRaV-4 (4a to d). Vines 2c and 3b also gave weak ELISA positives for GLRaV-4. Oligonucleotide primers were designed using nucleotide sequences obtained from the cloned GLRaV 4 RT-PCR product shown in Figure 1. The expected size for the amplification product was 441 nucleotides (nt). The 1-kb DNA ladder (Gibco BRL, Grand Island, NY) was used as a size marker (MW). The 506/517-nt doublet in this marker set (506/517) is marked to the left of the gel.

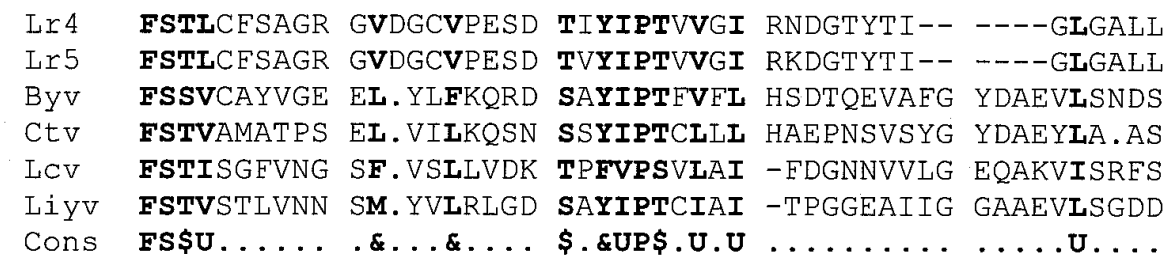

\begin{tabular}{|c|c|c|c|c|}
\hline $\operatorname{Lr} 4$ & EKDVLVYRDI KRYFGMNKFN & ANTYMMKLRP & KEEVLVKDWS & $-V S I G$ \\
\hline$c 5$ & EKDVLVYRDI KRYFGMNKFN & AEVYKKKLKP & KFEVIVKNWS & $-A Y I G$ \\
\hline$y v$ & SVRGGEYRDL KRWIGCDEEN & YGDYLEKLKP & HYKTELLKVA & QSSKSTVKLD \\
\hline $\mathrm{tv}$ & GESGSEYKDL KRWVGCTAKN & YQTYLHKLSP & SYKVIVKEFG & TKSVPVPYLS \\
\hline & DKEVQYY.DI KRWVGVSEKN & ENSLKEKISP & KYDCIEKN-- & $----N D C Y I S$ \\
\hline YV & TPHCFFY.DL KRWVGVDDNT & EKEAMNKIRP & KYVAELVE-- - & ---- GEVYLT \\
\hline ns & .......DU KR@\&G. & $\ldots \mathrm{KU} . \mathrm{P}$ &.$Y \ldots \&$. & \\
\hline
\end{tabular}

\begin{tabular}{|c|c|c|c|c|c|}
\hline 24 & $\mathrm{TR}$ & SVIALACMFV & SALAKLAVSI & TLSVC & \\
\hline $\operatorname{Lr} 5$ & PSSGEKGKTR & SVIALACMEV & SALAKMAVSI & GSAVKLSVC & \\
\hline$y v$ & CYSGTVPQNA & TLPGLIATEV & KALISTASEA & CQCTGVIC & \\
\hline tv & PLNNDLGLSV & ALPSLIASYA & KSILSDAERV & CTGVIC & \\
\hline $\mathrm{CV}$ & GVGTQ. KREL & PIRSLIYWYL & KILINLEEDQ & LKLKVNEVNI & \\
\hline iYv & GINKGFSIKL & SVKQLIKAYI & ETIVRLLASS & YSLRVIDLNQ & \\
\hline ons & & ...I. & . U. & & SVl \\
\hline$r 4$ & JFIEQGCNL & AKIQVQA & EPTAAG & ESIEY & MV \\
\hline$r 5$ & NFIFQGCNL & AKIQVQAVVN & EPTAAGLSAF & VTVDKNSIEY & MVV \\
\hline $\mathrm{gV}$ & SETESCVNL & SGYPCVYMVN & EPSAAALSAC & SRI-KGATSP & VLV \\
\hline tv & AFTQQSISM & SGYSCVYIIN & EPSAAAYSTL & PKL-NSADKY & LAV \\
\hline $\mathrm{CV}$ & RIYMRS IVNL & LGIPVRRIIN & EPSAAAMHQL & F-I-NPKENN & FVVE \\
\hline iyv & LAARSVLKA & LSEPCRRIIN & EPSAAAVYCV & $S-R-Y P N Y N Y$ & $\mathbf{F} L \mathbf{V}$ \\
\hline ons & & & PSAA & 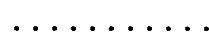 & \&.V \\
\hline
\end{tabular}

Fig. 3. PileUp (University of Wisconsin Genetics Computer Group) alignments of deduced amino acid sequences of cloned amplification products using degenerate primers designed to amplify a portion of the closterovirus heat shock protein 70 homolog (HSP70) gene (31) obtained by reverse-transcriptase polymerase chain reaction (RT-PCR) using double-stranded RNA obtained from grapevines serologically positive for grapevine leafroll-associated virus 4 (GLRaV-4) (LR4) or GLRaV-5 (LR5). Also shown are corresponding amino acid sequences for beet yellows virus (BYV) (2), citrus tristeza virus (CTV) (18), little cherry virus (LCV) (17), and lettuce infectious yellows virus (LIYV) (19). The consensus sequences (Cons) is also shown, with U indicating bulky aliphatic residues (I, L, V, or M), \$ for serine or threonine, \& for bulky hydrophilic residues (I, L, V, M, F, Y, or A), and @ for aromatic residues (F, $\mathrm{Y}$, or W). 
$4 \mu \mathrm{l}$ of $5 \times$ RT buffer [Promega Corp.], $1 \mu \mathrm{l}$ of RNasin [40 U/ $\mu \mathrm{l}$; Promega Corp.], $2 \mu \mathrm{l}$ of $0.1 \mathrm{M}$ dithiothreitol, $1 \mu \mathrm{l}$ of $10 \mathrm{mM}$ dNTPs, and 200 units of mouse mammary leukemia virus reverse transcriptase [Promega Corp.]). The entire reverse-transcription reaction was used in a hot-start PCR by adding $60 \mu \mathrm{l}$ of PCR solution $(8 \mu \mathrm{l}$ of $25 \mathrm{mM} \mathrm{MgCl}_{2}, 0.5 \mu \mathrm{l}$ of $1 \mu \mathrm{g} / \mu \mathrm{l}$ primer HSP4B, $8 \mu \mathrm{l}$ of PCR buffer II [Perkin-Elmer], and $43.5 \mu \mathrm{l}$ of $\mathrm{H}_{2} \mathrm{O}$ ), incubating for $2 \mathrm{~min}$ at $94^{\circ} \mathrm{C}$, adding $20 \mu \mathrm{l}$ of enzyme solution $(2 \mu \mathrm{l}$ of PCR buffer II, $17.5 \mu \mathrm{l}$ of $\mathrm{H}_{2} \mathrm{O}$, and $0.5 \mu \mathrm{l}$ of $5 \mathrm{U}$ of Taq DNA polymerase per $\mu$ l [Amplitaq; Perkin-Elmer]), and performing 40 cycles of PCR in a model 480 thermocycler (Perkin-Elmer). Reaction parameters were $94^{\circ} \mathrm{C}$ for $30 \mathrm{~s}, 64^{\circ} \mathrm{C}$ for $30 \mathrm{~s}$, and $72^{\circ} \mathrm{C}$ for $60 \mathrm{~s}$. A final incubation of $7 \mathrm{~min}$ at $72^{\circ} \mathrm{C}$ was followed by storage of samples at $4^{\circ} \mathrm{C}$. PCR products were analyzed by electrophoresis in $1.5 \%$ agarose gels.

RT-PCR detection of GLRaV-4 and GLRaV-5. A set of PCR primers intended to amplify a 370-nucleotide cDNA fragment from HSP70 genes of both GLRaV-4 and GLRaV-5 (primers HSP45A [3'-GTATCTYATGTACCAACAGAT-5'] and HSP45B [5'-GGTATGAACAARTTCAATGC-3']) were designed using nucleotide sequences obtained from degenerate primer RT-PCR of dsRNA extracted from plants infected with these two viruses. For reverse transcription, dsRNA was extracted from $7 \mathrm{~g}$ of $\mathrm{V}$. vinifera petioles as described above and resuspended in $20 \mu \mathrm{l}$ of sterile water. Reverse transcription was carried out (with primer HSP45A) as previously described, and PCR was carried out according to the same method as was used with primers HSP4A and HSP4B, except that the annealing temperature was $53^{\circ} \mathrm{C}$ rather than $64^{\circ} \mathrm{C}$ and the incubation times for melting and annealing were increased to $60 \mathrm{~s}$. In some reactions, recombinant Taq DNA polymerase (Gibco BRL) was used instead of Amplitaq.

\section{RESULTS}

dsRNA preparation. Six percent PAGE analysis of dsRNA, prepared by the method of Saldarelli et al. (28) from $30 \mathrm{~g}$ of $\mathrm{V}$. vinifera leaf petioles, revealed a series of large-molecular-weight dsRNAs in extracts of GLRaV-4-infected, but not healthy, tissue (Fig. 1A).

Degenerate primer RT-PCR. RT-PCR with degenerate HSP70 primers on dsRNA preparations from $V$. vinifera infected with GLRaV-4 and from Tetragonia expansa infected with beet yellows virus (BYV) produced nucleic acid products ranging in size from approximately 500 to $1,700 \mathrm{bp}$ (Fig. 1B). Amplification products of $500 \mathrm{bp}$ or larger were not observed with healthy grape tissue (Fig. 1B).
Cloning and sequencing of GLRaV-4 PCR products. The 550- to 650-bp PCR products produced from RT-PCR of dsRNA of BYV and GLRaV-4 were cloned into pGEM-T. A representative GLRaV-4 clone was used as a template for transcription of a DIG-labeled RNA probe that hybridized with dsRNA purified from GLRaV-4-infected, but not healthy, V. vinifera (Fig. 1C). A representative clone from the BYV PCR product matched the known nucleotide sequence (2). The sequences of four of the putative GLRaV-4 nucleotide sequences were identical, while a fifth clone contained 51 additional nucleotides, but was otherwise identical to the other four. These 51 nucleotides did not change the reading frame of the HSP70 gene and, therefore, either represent an inframe insertion in the longer sequence or an in-frame deletion in the shorter sequences. Since these 51 bp encode some amino acids conserved in the HSP70 region in other known closteroviruses, the longer sequence was used to represent the GLRaV-4 amplification product in subsequent analyses. Database comparisons of deduced peptide sequences using BLASTX (GCG) demonstrated significant homology $\left(P<\mathrm{e}^{-10}\right)$ between the GLRaV-4 clone and the HSP70 sequences found in BYV, citrus tristeza virus (CTV), lettuce infectious yellows virus (LiYV), and little cherry virus (LChV).

IC-RT-PCR. IC-RT-PCR amplification products of approximately 440 to $450 \mathrm{bp}$ were detected using primers HSP4A and HSP4B from four plants (of four tested) known to be infected with GLRaV-4 (Fig. 2, lanes $4 \mathrm{a}$ to d). The nucleotide sequence of this product matched the 441-bp amplification product that would be predicted from the nucleotide sequence of the larger GLRaV-4 clone. Amplification products of 440 to $450 \mathrm{bp}$ were detected in IC-RT-PCR of one plant that was serologically positive for GLRaV-2 and one plant that was serologically positive for GLRaV-3 (Fig. 2, lanes $2 \mathrm{c}$ and $3 \mathrm{~b}$ ). Subsequent serological analyses of these two plants revealed them to be multiply infected with numerous GLRaV types including GLRaV-4. The GLRaV-4 ELISA result for the plant whose amplification product is represented in Figure 2, lane 2c, was extremely weak (2.5 times the background reading, as opposed to 10 to 25 times the background for the GLRaV-4 ELISA readings corresponding to the other five plants in which amplification product was detected). No amplification products were detected in IC-RT-PCR of immunocaptured extracts of the remaining plants. Subsequent analyses were performed on four plants serologically positive for GLRaV-5 and serologically negative for GLRaV-4. No amplification products were detected in any of these plants. Since plants reliably known to be infected with GLRaV-6 and GLRaV-7 were not available at the time these studies were com-

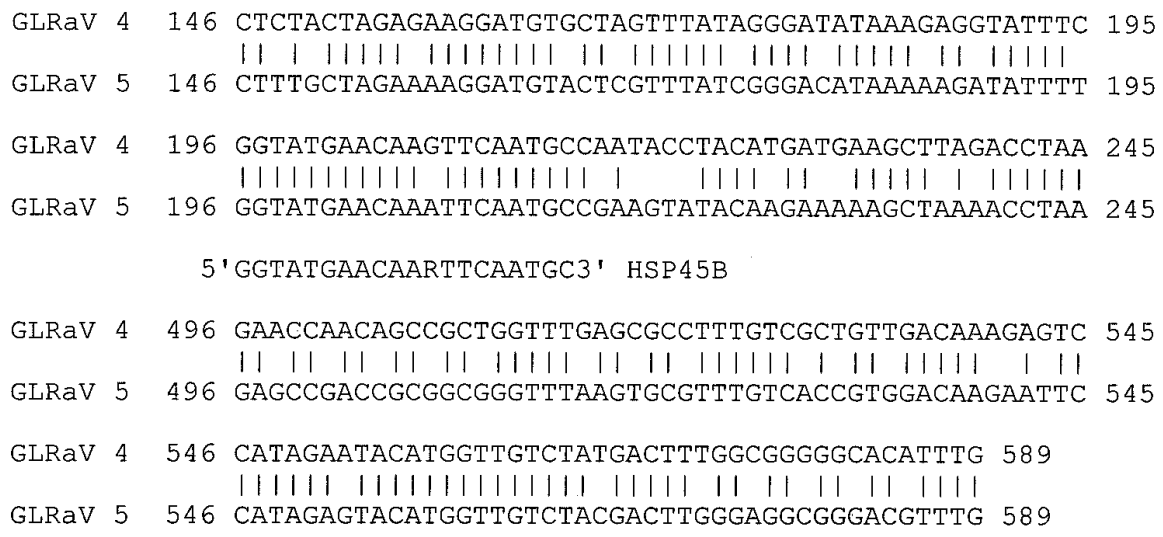

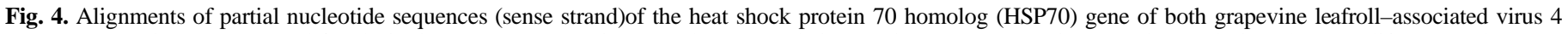

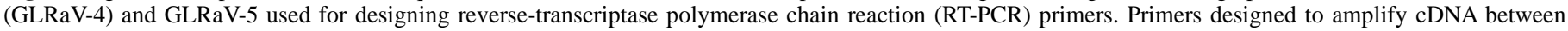

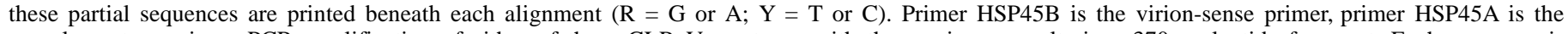

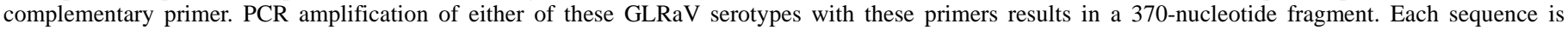
numbered to denote the distance from the $5^{\prime}$ terminus of the cloned fragment. 
pleted, no IC-PCR analyses were performed to confirm that the GLRaV-4 IC-PCR assay would not cross-react with these GLRaVs.

RT-PCR detection of GLRaV-4 and GLRaV-5 with one pair of primers. Cloning and sequencing of GLRaV-5 HSP70 cDNA were carried out in the same manner as described for GLRaV-4. Both nucleotide sequences were then submitted to GenBank under accession numbers AFO39553 (GLRaV-4) and AFO39552 (GLRaV5). Alignments (PileUp) between deduced proteins among the HSP70 sequences of GLRaV-4, GLRaV-5, BYV, CTV, LChV, and LIYV revealed numerous regions of peptide sequence homology (Fig. 3). Sequence comparisons (Gap) showed that the GLRaV-4 and GLRaV-5 HSP70 clones share 78\% nucleotide sequence identity and $91 \%$ amino acid sequence identity (93\% similarity). The nucleotide sequence information generated for GLRaV-4 and GLRaV-5 was then used to design a set of primers (HSP45A and HSP45B) capable of RT-PCR amplification of a 370-bp product from both leafroll virus types (Figs. 4 and 5). RT-PCR amplification, using dsRNA as a template, produced a DNA species of approximately $370 \mathrm{bp}$ from 9 plants (of nine tested) serologically positive for GLRaV-4 and no products from 12 plants serologically negative for GLRaV-4 and GLRaV-5, but serologically positive for various combinations of GLRaV-1, GLRaV-2, and GLRaV-3. Six V. vinifera vines serologically negative for GLRaV-4 and positive for GLRaV-5 were also analyzed. RT-PCR using dsRNA extracted from these plants produced amplification products of approximately $370 \mathrm{bp}$ in repeated experiments, but not from an uninfected plant. The amplification products obtained from the plants serologically positive for GLRaV-5 exhibited greater than $95 \%$ nucleotide sequence identity with each other and with the original GLRaV-5 degenerate primer PCR product and less than 78\% identity with GLRaV-4 HSP70 sequences.

\section{DISCUSSION}

Closteroviruses are the only viruses known to possess a gene encoding a HSP70 (31). Degenerate primers have been produced

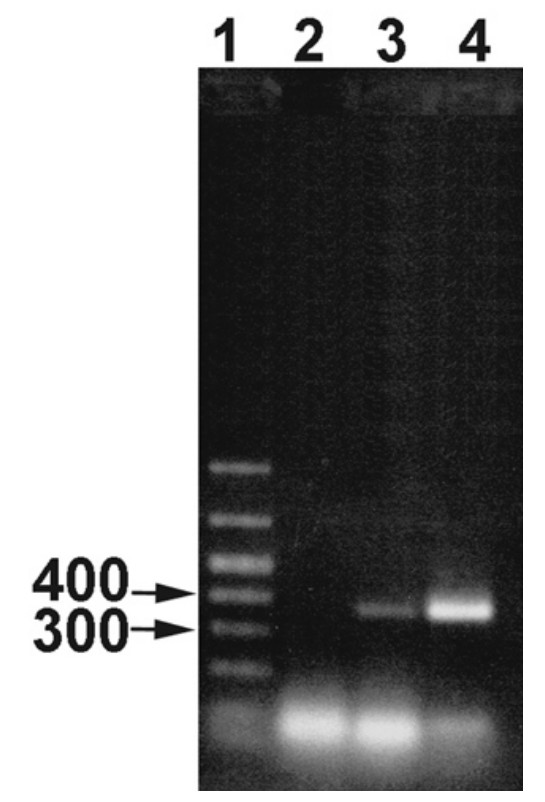

Fig. 5. Detection of both grapevine leafroll-associated virus 4 (GLRaV-4) and GLRaV-5 by reverse-transcriptase polymerase chain reaction (RT-PCR) using one primer pair. Agarose gel (1.5\%) containing Biomarker Low (Bioventures Inc., Murfreesboro, TN) molecular weight markers (lane 1) or PCR products. PCR was performed with both GLRaV-4 - and GLRaV-5-specific primers (Fig. 4) to amplify cDNA from double-stranded RNA prepared from uninfected Vitis vinifera (lane 2), V. vinifera enzyme-linked immunosorbent assay (ELISA) positive for GLRaV-4 and negative for GLRaV-5 (lane 3), or ELISA positive for GLRaV-5 and negative for GLRaV-4 (lane 4). The 300- and 400nucleotide Biomarker Low fragments (300 and 400, respectively) are shown to the left of the gel. that can be used to amplify sequences found within this gene from many or all of the known closteroviruses $(18,31)$. Since the GLRaVs are thought to be closteroviruses $(21,22)$, it was hypothesized that these primers should provide a useful tool for acquiring the nucleotide sequence information needed to produce RT-PCR- and ICRT-PCR-based detection methods for these pathogens. Since there is significant peptide sequence conservation within the HSP70 genes of the known closteroviruses $(18,31)$, it was considered likely that GLRaV HSP70 nucleotide sequences could be found that could be used to design oligonucleotides capable of priming RT-PCR amplification products from more than one type of these viruses.

Results presented in this paper show that RT-PCR with degenerate closterovirus HSP70 primers can be used to clone cDNA from plants serologically positive for GLRaV-4 and GLRaV-5. Furthermore, these results suggest that nucleotide sequence information obtained from these clones can be used to develop IC-RT-PCR detection protocols capable of detection of a specific grapevine leafroll virus type (in this case, GLRaV-4). It is not known for certain from these results whether this specificity extends to GLRaVs, both known and unknown, that were unavailable for this study. The fact that IC-RT-PCR using GLRaV-4-specific antisera and GLRaV-4-specific primers produced amplification products only with plants serologically positive for GLRaV-4, and not with plants serologically negative for GLRaV-4 and positive for the other GLRaVs studied here, does suggest the specificity of this assay. Care must be taken, however, when selecting antibodies for use in these IC-RT-PCR experiments, as IC-RT-PCR with the GLRaV-5 antibody gave consistently negative results with uninfected plants, but gave inconsistently positive results with infected plants (data not shown). This antisera gave consistently weak signals in ELISA of infected plants relative to the antisera used to detect GLRaV-1, GLRaV-2, GLRaV-3, and GLRaV-4, so it is possible that the antisera used in IC-RT-PCR with HSP70 primers has a strong affinity for virions. Alternately, it is possible that the primers used in these studies (HSP45A and HSP45B) were not as efficient as the ones designed specifically for the GLRaV-4 IC-RT-PCR. As these primers were used successfully in RT-PCR of dsRNA obtained from plants infected with GLRaV-4 and with GLRaV-5, this would seem unlikely. GLRaV HSP70 information was also useful for RT-PCR detection of more than one type in one reaction with one pair of primers. The results presented here suggest the possibility that these degenerate primers can be used to obtain nucleotide sequence information for most or all of the grapevine leafroll-associated putative closteroviruses and to develop efficient nucleic acid-based detection methods for them. This has immediate practical significance, as there is limited sequence information for this class of viruses $(12,13,20,28)$ and there are at least seven, and probably more, serologically distinct types $(5,6,16,23,30,36)$, requiring the continued production of a large number of antisera preparations. Methodologies based on PCR obviate the need for production and restocking supplies of antibodies for the routine detection of each of the growing number of GLRaV types.

Lastly, data presented here demonstrated that GLRaV-4 and GLRaV-5 contain at least a portion of a gene encoding a HSP70. This provides additional evidence that they are indeed closteroviruses.

\section{ACKNOWLEDGMENTS}

We thank G. Martelli for reviewing this manuscript and C. Eisele for her assistance with this project. This work was funded by the American Vineyard Foundation and Viticulture Consortium.

\section{LITERATURE CITED}

1. Abou-Ghanem, N., Sabanadzovic, S., Minafra, A., Saldarelli, P., Castellano, M. A., and Martelli, G. P. 1997. Physico-chemical and molecular characterization of grapevine leafroll-associated virus 2. Pages 15-16 in: Extended Abstracts Meeting ICVG, 12th. International Council 
for the Study of Viruses and Virus Diseases of the Grapevine.

2. Agranovsky, A. A., Boyko, V. P., Karasev, A. V., Koonin, E. V., and Dolja, V. V. 1991. Putative-65 Kda protein of beet yellows closterovirus is a homologue of Hsp70 heat shock proteins. J. Mol. Biol. 217:603-610.

3. Altschul, S. F., Boguski, M. S., Gish, W., and Wootton, J. C. 1994. Issues in searching molecular sequence databases. Nat. Genet. 6:119-129.

4. Altschul, S. F., Gish, W., Miller, W., Myers, E. W., and Lipman, D. J. 1990. Basic local alignment search tool. J. Mol. Biol. 215:403-410.

5. Bovey, R., and Martelli, G. P. 1992. Directory of Major Virus and Viruslike Diseases of Grapevines. Descriptions, Historical Review and Bibliography. Mediterranean Fruit Crop Improvement Council and International Council for the Study of Viruses and Virus Diseases of Grapevine.

6. Choueiri, E., Boscia, D., Digiaro, M., Castellano, M. A., and Martelli, G. P. 1996. Some properties of a hitherto undescribed virus of the grapevine. Vitis 35:91-93.

7. Devereux, J., Haeberli, P., and Smithies, O. 1984. A comprehensive set of sequence analysis programs for the VAX. Nucleic Acids Res. 12:387-395.

8. Forsline, P. L., Hoch, J., Lamboy, W. F., Hu, J. S., McFerson, J. R., Golino, D. A., and Gonsalves, D. 1996. Comparative effectiveness of symptomatology and ELISA for detecting two isolates of grapevine leafroll in Cabernet Franc. Am. J. Enol. Vitic. 47:239-243.

9. Goheen, A. C. 1988. Diseases caused by virus and virus-like agents. Pages 47-54 in: Compendium of Grape Diseases. R. C. Pearson and A. C. Goheen, eds. The American Phytopathological Society, St. Paul, MN.

10. Goheen, A. C., and Cook, J. A. 1959. Leafroll (red-leaf or rougeau) and its effects on vine growth, fruit quality and yields. Am. J. Enol. Vitic. 10: 78-84.

11. Golino, D. A. 1992. The Davis grapevine virus collection. Am. J. Enol. Vitic. 43:200-205.

12. Habili, N., Fazeli, C. F., and Rezaian, M. A. 1997. Identification of a cDNA clone specific to grapevine leafroll-associated virus 1, and occurrence of the virus in Australia. Plant Pathol. 46:516-522.

13. Habili, N., and Rezaian, M. A. 1995. Cloning and molecular analysis of double stranded RNA associated with grapevine leafroll disease. Ann. Appl. Biol. 127:95-103.

14. Hoefort, L. L., and Gifford, E. M. 1967. Grapevine leafroll virus-History and anatomical effects. Hilgardia 38:403-426.

15. Hu, J. S., Gonsalves, D., Boscia, D., and Namba, S. 1990. Use of monoclonal antibodies to characterize grapevine leafroll associated closteroviruses. Phytopathology 80:920-925.

16. Hu, J. S., Gonsalves, D., and Teliz, D. 1990. Characterization of closterovirus-like particles associated with grapevine leafroll disease. J. Phytopathol. 128:1-14.

17. Jelkmann, W., Fechtner, B., and Agranovsky, A. A. 1997. Complete genome structure and phylogenetic analysis of little cherry virus, a mealybug-transmissible closterovirus. J. Gen. Virol. 78:2067-2071.

18. Karasev, A. V., Nikolaeva, O. V., Koonin, E. V., Gumpf, D. J., and Garnsey, S. D. 1994. Screening the closterovirus genome by degenerate primer mediated polymerase chain reaction. J. Gen. Virol. 75:1415-1422.

19. Klaassen, V. A., Boeshore, M. L., Koonin, E. V., Tian, T. Y., and Falk, B. W. 1995. Genome structure and phylogenetic analysis of lettuce infectious yellows virus, a whitefly-transmitted, bipartite closterovirus. Virology 20:99-110.

20. Ling, K. S., Zhu, H. Y., Alvizo, H., Hu, J. S., Drong, R. F., Slightom, J. L., and Gonsalves, D. 1997. The coat protein gene of grapevine leafroll associated closterovirus-3: Cloning, nucleotide sequencing and expression in transgenic plants. Arch. Virol. 142:1101-1116.

21. Martelli, G. P., ed. 1993. Graft-transmissible diseases of grapevine. Pages 37-44 in: Handbook for Detection and Diagnosis. Food and Agricultural Organization of the United Nations and the International Council for the Study of Viruses and Virus Diseases of Grapevine.

22. Martelli, G. P., Saldarelli, P., and Boscia, D. 1997. Filamentous viruses of grapevine: Closteroviruses. Pages 1-9 in: Recent Research Development in Plant Pathology_Filamentous Viruses of Woody Plants. P. L. Monette, ed. Research Signpost, Trivandrum, India.

23. Namba, S., Yamashita, S., Doi, Y., Yora, K., and Yano, R. 1979. Grapevine leafroll virus a possible member of the closteroviruses. Ann. Phytopathol. Soc. Jpn. 45:497-502.

24. Rowhani, A. 1992. Use of $F\left(a b^{\prime}\right) 2$ antibody fragment in ELISA for detection of grapevine viruses. Am. J. Enol. Vitic. 43:38-40.

25. Rowhani, A., Chay, C., Golino, D. A., and Falk, B. W. 1993. Development of a polymerase chain reaction technique for the detection of grapevine fanleaf virus in grapevine tissue. Phytopathology 83:749-753.

26. Rowhani, A., Maningas, M. A., Lile, L. S., Daubert, S. D., and Golino, D. A. 1995. Development of a detection system for viruses of woody plants based on PCR analysis of immobilized virions. Phytopathology 85:347-352.

27. Rowhani, A., Uyemoto, J. K., and Golino, D. A. 1997. A comparison between serological and biological assays in detecting grapevine leafroll associated viruses. Plant Dis. 81:799-801.

28. Saldarelli, P., Minafra, A., Martelli, G. P., and Walter, B. 1994. Detection of grapevine leafroll-associated closterovirus III by molecular hybridization. Plant Pathol. 43:91-96.

29. Sambrook, J., Fritsch, E. F., and Maniatis, T. 1989. Molecular Cloning: A Laboratory Manual. Cold Spring Harbor Laboratory Press, Cold Spring Harbor, NY.

30. Tanne, E., Ben-Dov, Y., and Raccah, B. 1989. Transmission of closterolike particles associated with grapevine leafroll by mealybugs (Pseudococcidae) in Israel. Pages 71-73 in: Extended Abstracts Meeting ICVG, 9th. International Council for the Study of Viruses and Virus Diseases of the Grapevine.

31. Tian, T., Klaassen, V. A., Soong, J., Wisler, G., Duffus, J. E., and Falk, B. W. 1996. Generation of cDNAs specific to lettuce infectious yellows closterovirus and other whitefly-transmitted viruses by RT-PCR and degenerate oligonucleotide primers corresponding to the closterovirus gene encoding the heat shock protein 70 homolog. Phytopathology 86:1167-1173.

32. Valverde, R. A., Nameth, S. T., and Jordan, R. L. 1990. Analysis of double-stranded RNA for plant virus diagnosis. Plant Dis. 74:255-258.

33. Weber, E., Golino, D., and Rowhani, A. 1993. Leafroll disease of grapevines. Pract. Winery Vineyard 13:21-25.

34. Woodrum, R. C., Antcliff, A. J., Krake, L. R., and Taylor, R. H. 1984. Yield differences between sultana clones related to virus status and genetic factors. Vitis 23:73-83.

35. Zhu, H. Y., Ling, K. S., and Gonsalves, D. 1997. Nucleotide sequence and genome organization of grapevine leafroll-associated closterovirus 2. Page 17 in: Extended Abstracts Meeting ICVG, 12th. International Council for the Study of Viruses and Virus Diseases of the Grapevine.

36. Zimmerman, D., Bass, B., Legin, R., and Walter, B. 1990. Characterization and serological detection of four closterovirus-like particles associated with leafroll disease of grapevine. J. Phytopathol. 130:205-218. 